\title{
Lung Body Plethysmography: From Functional to Clinical Aspects for Prediction of Quality of Life in Patients with Chronic Pulmonary Obstruction
}

\author{
ROXANA MARIA NEMES ${ }^{1}$, FLORENTINA LIGIA FURTUNESCU ${ }^{2, *}$, IOAN SORIN TUDORACHE ${ }^{1}$, TUDOR HARSOVESCU', \\ ALEXANDRA FLORIANA NEMES ${ }^{2}$, MIRONELA PIRNAU3 \\ ${ }^{1}$ Titu Maiorescu University, Faculty of Medicine, 67A Gheorghe Petrascu Str, 031593, Bucharest, Romania \\ ${ }^{2}$ Carol Davila University of Medicine and Pharmacy, 8 Eroii Sanitari Blvd, 050474, Bucharest, Romania \\ ${ }^{3}$ Titu Maiorescu, Faculty of Informatics, 189 Calea Vacaresti Str, 0400511, Bucharest Romania
}

\begin{abstract}
We analyze the lung function using advanced measurement (body plethysmography) and standard measurement (spirometry) in stable COPD (Chronic Obstructive Pulmonary Disease) patients. Subjects and methods: 211 patients with stable COPD (88.6\% males) age 61 5 years (mean \pm standard deviation), exsmokers 78.7\%, underwent to: body pletysmography , spirometry, electrocardiography. Parameters obtained: residual volume (RV), forced expiratory volume in I second ( $F E V$ ), were correlated with different parameters and also for prediction of quality of life in COPD patients. In assessing the quality of life we used the St. George's Respiratory Questionnaire (SGRQ). According to BMI (body mass index) we classify patients in four groups: 1. underweight $(<20, n=34)$, 2. normal weight $(20-24, n=79)$, 3. overweight (25$29.9, n=58)$, 4 . obese ( $>30, n=40), n=$ number of patients.
\end{abstract}

Keywords: body plethysmography, COPD, quality of life.

COPD currently occupies sixth place on the list of causes of morbidity in the world in the adult population and tends to arrive in third place in the non-smoking 2030 [1]. The cost of the disease is very high $[2,3]$.

Pulmonary functional tests are essential for diagnosis in patients with COPD. Spirometry is considered the most reproducible, and routine test in measuring airflow limitation. In COPD diagnosis relies mainly by highlighting the obstruction using $\mathrm{FEV}_{1}[2,4]$.

St. George's Respiratory Questionnaire (SGRQ) was developed by PW Jones et al. being the most commonly used questionnaire in assessing the quality of life in chronic respiratory diseases (bronchial asthma, COPD), particularly in COPD [5]. It includes 76 questions grouped into three areas: symptoms, activity, impact. True or false responses are subsequently converted into numerical scale, resulting in field-specific scores and overall scores, which thus allow statistical processing of patient-provided information. The values of these scores are in the range 0-100, where 0 quantifies perfect quality of life, and 100 a maximum impact on quality of life related to health. The questionnaire can be: self-administered or administered by interview, frequently being self-administered. The time required for administration is approximately 20 minutes. We used a self-administered questionnaire for our research.

During forced expiratory maneuvers, patients with COPD can assist in decreasing $\mathrm{FEV}_{1}$. This occurs with the severity of the disease. Increasing the effort produces a compression on the thorax gas (Boyle's law): $\mathrm{pV}=$ constant ( $p=$ pressure, $V=$ volume), which leads to the reduction of the pulmonary volume and implicitly to the reduction of $F E V$. This is all the more pronounced as the residual volume $(R V)$ is higher (severe hyperinflation). HRQL is a global measure that integrates more biological effects, unlike spirometric variables (FEV1) that measure a single biological variable [6]. Starting from these premise, HRQL measurement is important for at least two reasons, somewhat related to each other: -assessing the impact of the disease on the patient's life, which is of much greater interest to it than the classical assessment of disease severity $\left(\mathrm{FEV}_{1}\right)$;

-assessing the impact of the disease on the patient's life, which is of much greater interest to it than the classical assessment of disease severity $\left(\mathrm{FEV}_{1}\right)$;

\section{Experimental part}

Material and methods

In this prospective study, 211 patients with stable COPD $(87.7 \%$ males) age $61 \pm 5$ years (mean \pm standard deviation), underwent to: spirometry, body plethysmography and echocardiography. There were 145 ex-smokers $(77.7 \%)$ and 66 current smokers with a number of packyear (PA): $33.3 \pm 7.7$.

The recruitment of patients was carried out according to the following inclusion and exclusion criteria: Inclusion criteria:

-clinical-functional diagnosis of COPD

- history of smoker> 20 PA.Calculation no. packets-year (PA) according to the formula:

$$
P A=\sum_{i} \frac{x_{i}}{20} \times n_{i}
$$

$x_{i}=$ number of cigarettes smoked per day

$n_{i}=$ period in years corresponding to $x$

-patient's inform consent of complex lung investigation and to use the data for the present research.

Exclusion criteria: diagnosis of bronchial asthma, the uncertainty of the diagnosis, lack of anamnestic data, the impossibility of performing complex lung investigations, exacerbation in the last 30 days before lung function tests $[7,8]$.

Spirometry was performed using a flowscreen Jaeger daily calibrated and check the validation of each registration data. The parameters measured by spirometry were: vital capacity (VC), flow expiratory volume in one 
second of an expiratory forced manouver $\left(\mathrm{FEV}_{1}\right)$, ratio $\mathrm{FEV}_{\mathrm{I}} \mathrm{I}$ VC, maximal expiratory flow at $50 \%$ of vital capacity (MEF50). The parameters values are express in liter (L) or percent of predicted value. We performed body plethysmography for measure TLC (total lung capacity), residual volume (RV), cuantify the level of hyperinflation. We expressed RV as percent of predicted value (VRP\%).

The equipment used is a Masterscreen Jaeger body plethysmograph. It is a plethysmograph equipped with an automatic calibration system according to temperature and pressure in the environment. The transparent plethysmograph allows the contact with the patient to perform maneuver, both visually and vocally.

Bodypletysmography technique: we explains in details for the patient the maneuvers to be executed; the subject will sit in the body pletysmograph cabin and, after closing the cabin door, will wait for a minute to breathe quietly; then the patientis asked to breathe through the mouthpiece attached to a pneumotograph; from now on, the patient will have the nostrils until the maneuvers are over [9]. After some quiet breathing maneuvers the patient will deeply inhale against a shutter by a technician who interrupts very short the airflow to the mouth; then exhale and inhale until the complete maneuvers that allow for a spirometry after the rupture of the obstacle the patient will be carefully supervised for the very duration of the tests to achieve very good cooperation. The physician monitors throughout the entire sample of the sample and graphically plotted on the computer monitor and the alveolar volume-volume loop recording (Figure 1), where VR - residual volume, $\mathrm{Cl}$ inspiratory capacity, VER - spare expiratory volume.

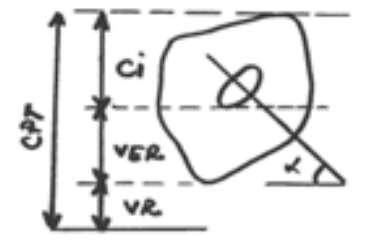

Fig 1 Volume-alveolar pressure loop during bodypletysmography

Parameters obtained allow the assessment of the central resistance to flow (Raw), residual volume (VR) and total pulmonary capacity, being the only method that allows the total determination of these pulmonary volumes. Ecocardiography was done to identify the elements of chronic cor pulmonare.

We calculate $\mathrm{BMI}=$ weight $/$ height $^{2}\left(\mathrm{~kg} / \mathrm{m}^{2}\right)$ and classified patients in four groups according to BMI ( $n=$ number of patients):

$\mathrm{BMI}<20$ (underweight), $n=34$

$20 \leq \mathrm{BMI} \leq 25$ (normal weight), $\mathrm{n}=79$

$26 \leq \mathrm{BMI} \leq 29$ (overweight), $\mathrm{n}=58$

$\mathrm{BMI} \geq 30$ (obese), $\mathrm{n}=40$

We used the GOLD (Global Initiative for Chronic Obstructive Lung Disease) classification for severity of obstruction consider only the post - bronchodilator FEV1 value $[10,11]$ :

1. FEV $1 \geq 80 \%$ of predicted value, $n=6$

2. $50 \% \leq$ FEV $1<80 \%$ of predicted value, $n=53$

3. $30 \% \leq$ FEV $1<50 \%$ of predicted value, $n=108$

4. FEV $1<30 \%$ of predicted value, $n=44$

For analyze hyperinflation we used three groups of severity as VRP\% of predicted value:

1.Mild $130 \% \leq$ VRP $\%<180 \%$

2.Moderate $180 \% \leq$ VRP $\%<240 \%$

3. Severe VRP $\% \geq 240 \%$

Data analysis was performed using the EPIINFO6, EXCEL, SPSS statistical programs using the functions and modules of these programs. The following statistical tests were used:
- the test $\chi 2$ (Chi square) and its variants (Yates corrected, Mantel-Haentszel, exact Fisher) for discrete variables (categorical, including dichotomous ones)

- the Student ( $T$ ) test: comparing 2 lots by comparing their averages for the same variable having a parametric distribution (normally distributed)

- Mann-Whitney (U) test comparing more than 2 lots by comparing their averages for the same variable with nonparametric distribution

-Anova test (A) comparing more than 2 batches by comparing their averages for the same variable with parametric distribution.

\section{Results and discussions}

211 patients were enrolled according to the inclusion criteria listed above. The study group has the following characteristics listed in Table 1.

Table 1

CLINICAL AND DEMOGRAPHIC DATA

\begin{tabular}{|l|c|}
\hline CARACTERISTICS & $\begin{array}{c}\text { Means } \pm \text { standard } \\
\text { deviation (\%) }\end{array}$ \\
\hline Age (years) & $62.05 \pm 9.4$ \\
\hline Gender & $187(88.6 \%)$ \\
- male & $24(11.4 \%)$ \\
- female & $45(21.3 \%)$ \\
\hline Smoking status & $166(78.7 \%)$ \\
- smokers & $42.7 \pm 15.3$ \\
- exsmokers & $149(70.6 \%)$ \\
- PA & $62(29.4 \%)$ \\
\hline Leave & \\
- urban & rural
\end{tabular}

We obtained the follow values of functional respiratory parameters for entire group (tabel 2).

Table 2

FUNCTIONAL RESPIRATORY PARAMETERS FOR ENTIRE GROUP $(\mathrm{N}=211)$

\begin{tabular}{||l|c|c|c|c||}
\hline & Means & $\begin{array}{l}\text { Standard } \\
\text { deviation }\end{array}$ & $\begin{array}{l}\text { Minimum } \\
\text { value }\end{array}$ & $\begin{array}{l}\text { Maximum } \\
\text { value }\end{array}$ \\
\hline FEV1 (l) & 1.2 & 0.53 & 0.4 & 3.6 \\
\hline FEV1\% & 42.6 & 15.9 & 14 & 94 \\
\hline FEV1/VC*100 & 49.5 & 10.6 & 27.2 & 77.2 \\
\hline MEF 50 & 15.4 & 9.8 & 2.9 & 54.7 \\
\hline VRP \% & 227.7 & 60.0 & 102.5 & 475.8 \\
\hline TLC \% & 122.6 & 20.2 & 85.1 & 180.3 \\
\hline
\end{tabular}

From Figure 2 it can be seen that $\mathrm{FEV}_{1} \%$ (vemsp\%) varies inversely with VRP\% values. There is a modest negative correlation (Pearson) between these two parameters $(R=-0.43)$. The tendency of the $\% \mathrm{FEV}_{1} \%$ parameter is descending to VRP\% as shown by the regression equation in the above image

$$
\text { (VRP\% } \left.=-1,662 . \mathrm{FEV}_{1} \%+297.88\right)
$$

Related to smoking status we found that men start to smoke earlier than women $(p=0.0001, S)$ (table 3).

Analyzing the three groups of hyperinflation severity we identified that for group 1 (mild hyperinflation 130\% $\leq$ VRP\% $<180 \%$ ) we have a total of 44 patients who consumed a total of 1545 PA, while patients in group 2 (moderate 


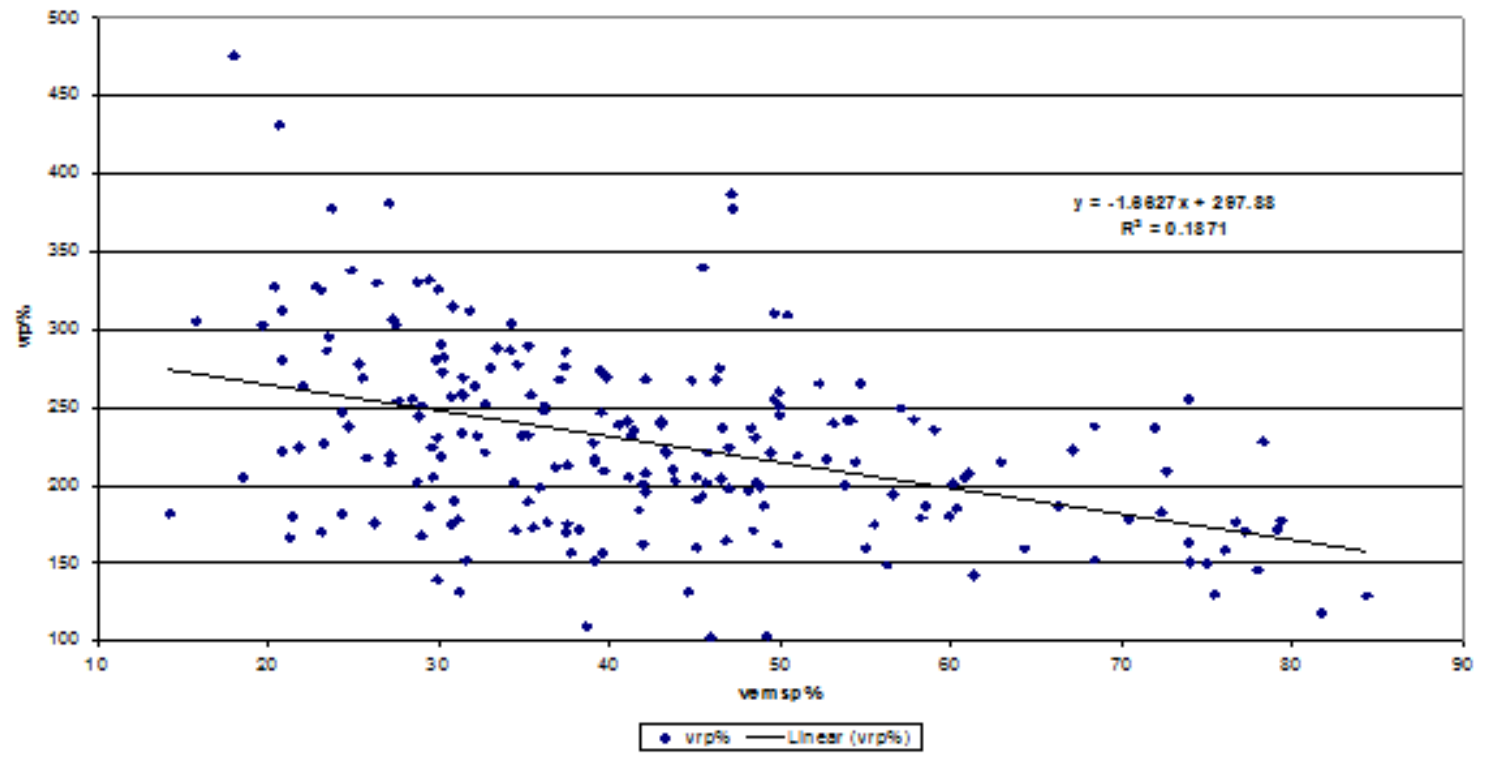

Fig. 2. Relation between vemsp $\%\left(\mathrm{FEV}_{1} \%\right)$ and $\mathrm{vrp} \%$

\begin{tabular}{||l|l|l|l|l||}
\hline & $\begin{array}{l}\text { Male } \\
\mathbf{n = 1 8 7}\end{array}$ & $\begin{array}{l}\text { Female } \\
\mathbf{n = 2 4}\end{array}$ & $\begin{array}{l}\text { Statistical } \\
\text { signifficance }\end{array}$ & Test \\
\hline Age start smoking & $20.6 \pm 6.4$ & $26 \pm 8.1$ & $\mathrm{p}=0.0001, \mathrm{~S}$ & T test \\
\hline Age stop smoking & $56.3 \pm 9.5$ & $58 \pm 9.02$ & $\mathrm{p}=0.451, \mathrm{NS}$ & T test \\
\hline PA & $43.9 \pm 15.3$ & $33 \pm 11.3$ & $\mathrm{p}=0.001, \mathrm{~S}$ & T test \\
\hline
\end{tabular}

PA = pack -year; parameters are expressed as means \pm drs (standard deviation)

hyperinflation $180 \% \leq \mathrm{VRP} \%<240 \%$ ) consumed a total of 3267PA, and the number of patients being analyzed was 81. It results that for the same time period analyzed, the number of patients doubled, whereas between the arithmetic mean of consumption of the packets of the two classes there was a the very small difference, its value being 4.05 ( $p>0.001$ ). Group 3 (severe hyperinflation VRP\% $\geq 240 \%$ ) contains 75 patients who together consumed the highest number of PA as shows in fia. 3.

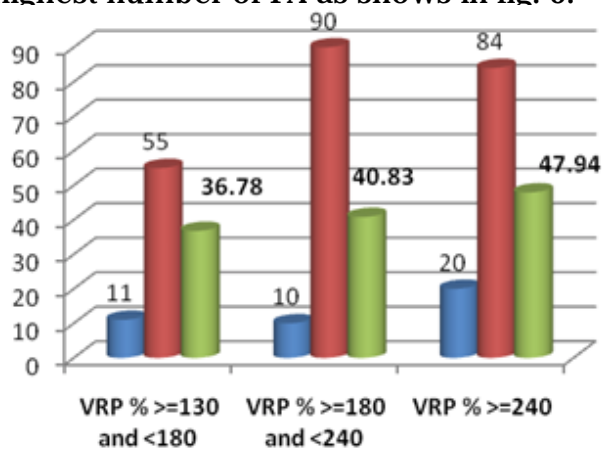

- MIN. PA.

MAX.PA.

IVERAGE PA.

Fig. 3 . A comparison of the minimum, maximum and average package distributions related with hyperinflation severity groups

\begin{tabular}{|c|c|c|}
\hline $\begin{array}{c}\text { GOLD } \\
\text { STAGES }\end{array}$ & Regresion equation & Correlation coeficient \\
\hline $\begin{array}{c}\text { GOLD } 1 \\
n=6\end{array}$ & $\mathrm{VRP} \%=-6.663^{*} \mathrm{FEV}_{1} \%+684.5$ & $\begin{array}{l}\mathrm{R}=-0.64 \\
\text { (Pearson) }\end{array}$ \\
\hline $\begin{array}{c}\text { GOLD } 2 \\
n=53\end{array}$ & $\mathrm{VRP} \%=-2.005^{*} \mathrm{FEV} \%+328.56$ & $\begin{array}{l}\mathrm{R}=-0.42 \\
\text { (Pearson) }\end{array}$ \\
\hline $\begin{array}{c}\text { GOLD } 3 \\
n=108\end{array}$ & VRP $\%=-0.071 * \mathrm{FEV}_{1} \%+267.75$ & $\begin{array}{l}\mathrm{R}=-0.10 \\
\text { (Pearson) }\end{array}$ \\
\hline $\begin{array}{c}\text { GOLD } 4 \\
\mathrm{n}=44\end{array}$ & $\mathrm{VRP} \%=-3.244 * \mathrm{FEV} \%+344.82$ & $\begin{array}{l}\mathrm{R}=-0.17 \\
\text { (Pearson) }\end{array}$ \\
\hline
\end{tabular}
$=0.007$ ) as shown (Table 5). patients $(p=0.27, A)$.
Table 3

SMOKING HISTORY FOR THE TWO CATEGORIES (MALE, FEMALE)

Below are the regression equations obtained for the VRP\% value depending on the four GOLD stages of the obstruction verticality. (Table 4). Those with severe ventilator dysfunction (GOLD 4) showed significantlyhigher pulmonary hyperinflation values than those in GOLD 1 ( $p$

Comparing the mean values and standard deviations of VRP\% ( see table 6) for subgroups of patients with different nutritional status (goups BMI 1,3,4) versus those with BMI group 2 (normoponderal) we found no significantly difference in underweight patients versus normoponderal

The first sign of the alarm is that $61.6 \%$ (130/211) of the subjects analyzed started to smoke before the age of 20 years (table 7). Also, 70\% of overweight young people began to smoke before 20 years, and $13 \%$ of them had severe hyperinflation. (VRP\%> 240\% of predicted value).

The VRP\% analysis with smoker status highlighted a large dispersion of PA values (Figure 4) and a lack of linear correlation between PA and VRP\% ( $R=0.01$, Pearson). The same high displacement of VRP\% by PA was also 


\begin{tabular}{|c|c|c|c|c|c|}
\hline \multirow{2}{*}{$\begin{array}{l}\text { GOLD } \\
\text { stages }\end{array}$} & \multicolumn{4}{|c|}{ VRP $\%$} & \multirow[b]{2}{*}{ Test } \\
\hline & $\mathbf{n}$ & Means & $\begin{array}{l}\text { Standard } \\
\text { deviation }\end{array}$ & p-value & \\
\hline 1 & 2 & 122.5 & 7.7 & \multirow{2}{*}{$\begin{array}{c}\mathrm{P}=0.01 \\
(\mathrm{~S})\end{array}$} & \multirow[t]{2}{*}{ A } \\
\hline 2 & 53 & 204.7 & 43 & & \\
\hline 1 & 2 & 122.5 & 7.7 & \multirow{2}{*}{$\begin{array}{c}\mathrm{P}=0.008 \\
(\mathrm{~S})\end{array}$} & \multirow{2}{*}{ A } \\
\hline 3 & 108 & 224.3 & 52.8 & & \\
\hline 1 & 2 & 122.5 & 7.7 & \multirow{2}{*}{$\begin{array}{c}\mathbf{p}=0.007 \\
(\mathrm{~S})\end{array}$} & \multirow{2}{*}{ A } \\
\hline 4 & 44 & 268.5 & 71.9 & & \\
\hline
\end{tabular}

Table 5

DISTRIBUTION OF MEAN VALUES OF VRP\% BY SUBGROUPS OF SEVERITY OF BRONCHIAL OBSTRUCTION

\begin{tabular}{|c|c|c|c|c|c|}
\hline \multirow[b]{2}{*}{ BMI groups } & \multicolumn{4}{|c|}{ VRP $\%$} & \multirow[b]{2}{*}{ Test } \\
\hline & $\mathbf{n}$ & Means & $\begin{array}{l}\text { Standard } \\
\text { deviation }\end{array}$ & p - value & \\
\hline 3 & 58 & 219.1 & 49.3 & \multirow{2}{*}{$\begin{array}{l}0.12 \\
\text { NS }\end{array}$} & \multirow[t]{2}{*}{$\mathbf{A}$} \\
\hline 2 & 79 & 226.4 & 64.4 & & \\
\hline 1 & 34 & 220.5 & 52.7 & \multirow{2}{*}{$\begin{array}{l}0.27 \\
\mathrm{NS}\end{array}$} & \multirow[t]{2}{*}{$\mathbf{A}$} \\
\hline 2 & 79 & 226.4 & 64.4 & & \\
\hline 4 & 44 & 255.4 & 67.7 & \multirow{2}{*}{$\begin{array}{c}0.046 \\
\mathrm{~S}\end{array}$} & \multirow{2}{*}{$\mathbf{A}$} \\
\hline 2 & 79 & 226.4 & 64.4 & & \\
\hline
\end{tabular}

Table 6

DISTRIBUTION OF PERCENTAGE VALUES OF VRP\% BY BMI GROUPS

Table 7

THE OCCURRENCE FREQUENCIES OF PATIENTS WITH START TO SMOKE BEFORE 20 YEARS OLD, REPORTED FOR EACH BMI GROUP.

\begin{tabular}{|c|c|c|c|c|c|c|c|}
\hline $\begin{array}{l}\text { BMI } \\
\text { groups } \\
\left(\mathrm{kg} / \mathrm{m}^{2}\right)\end{array}$ & $\begin{array}{l}\text { Nr of } \\
\text { patients } \\
\quad(n=211)\end{array}$ & $\begin{array}{l}\text { Nr of patients } \\
\text { (start to } \\
\text { smoke before } \\
20 \text { years old) }\end{array}$ & $\begin{array}{c}\text { Frecq of } \\
\text { appearence }\end{array}$ & $\begin{array}{l}\text { Nr of patients } \\
\text { (VRP } \%=240 \text { ) }\end{array}$ & $\begin{array}{l}\text { Frequency of } \\
\text { appearencefor } \\
\text { VRP } \%=240\end{array}$ & $\begin{array}{l}\text { Nr patients } \\
\text { with } \\
\text { cor } \\
\text { pulmonale }\end{array}$ & $\begin{array}{l}\text { Frecquency of } \\
\text { appearance for } \\
\text { cor pulmonale }\end{array}$ \\
\hline$<20$ & 34 & 20 & $59 \%$ & 14 & $41 \%$ & 2 & $6 \%$ \\
\hline$[20,25]$ & 79 & 51 & $65 \%$ & 23 & $29 \%$ & 5 & $6 \%$ \\
\hline$(25,30]$ & 58 & 31 & $53 \%$ & 27 & $47 \%$ & 5 & $9 \%$ \\
\hline$>30$ & 40 & 28 & $70 \%$ & 5 & $13 \%$ & 2 & $5 \%$ \\
\hline
\end{tabular}

obtained for patients who were smokers at the time of the determinations (Figure 5).

The additional exposure to industrial chemicals, dust, gases or presence of comorbidities such as diabetes mellitus, hypertension, tuberculosis, pulmonary neoplasm, other neoplasms and infections may be risk factors correlated with the severity of hyperinflation [12-17].

By analyzing the additional exposure to noxius substances we found no contribution as risk factors for the increase in residual volume in patients in the global group (Table 9).

Patients with chroniccor pulmonale have a higher risk to associate severe hyperinflation (table 10) than those who did not have chronic pulmonary heart disease ( $p$ $=0.0001$ ).

The analysis of the links between the scores of the quality of life questionnaire (tabel 10) for the 211 patients who received the questionnaire, found that there were no differences in the impact score (SGRQi), activity score 

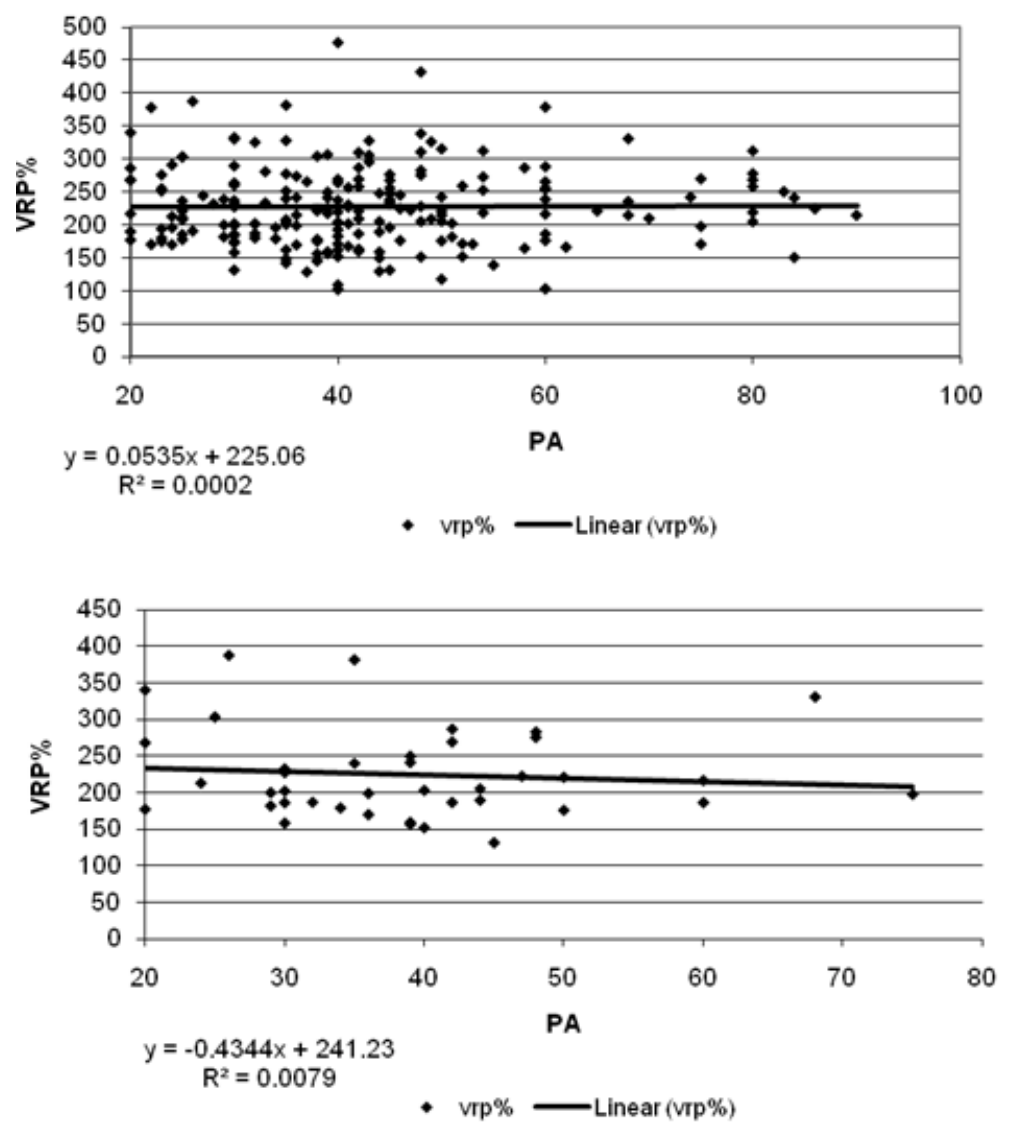

\begin{tabular}{|c|c|c|c|c|c|}
\hline & & \multicolumn{4}{|c|}{ VRP\% } \\
\hline & & $\mathbf{n}$ & Mean & $\begin{array}{l}\text { Standard } \\
\text { deviation }\end{array}$ & $\begin{array}{l}\text { Statistical } \\
\text { signification }\end{array}$ \\
\hline \multirow{2}{*}{$\begin{array}{c}\text { Start } \\
\text { smoking }\end{array}$} & $\begin{array}{c}\text { YES } \\
(<25 \text { years old })\end{array}$ & 158 & 231.7 & 60.3 & \multirow{2}{*}{$\begin{array}{c}p=0.08 \\
(A) \\
N S\end{array}$} \\
\hline & $\begin{array}{c}\text { NO } \\
\Leftrightarrow 25 \text { years old })\end{array}$ & 53 & 225.4 & 62.6 & \\
\hline \multirow[t]{2}{*}{ PA } & $\begin{array}{c}\text { YES } \\
(>30 \text { years old })\end{array}$ & 172 & 229.2 & 61.0 & \multirow{2}{*}{$\begin{array}{c}p=0.08 \\
\text { (A) } \\
\text { NS }\end{array}$} \\
\hline & $\begin{array}{c}\text { NO } \\
(<30 \text { years old })\end{array}$ & 39 & 218.7 & 53.8 & \\
\hline
\end{tabular}

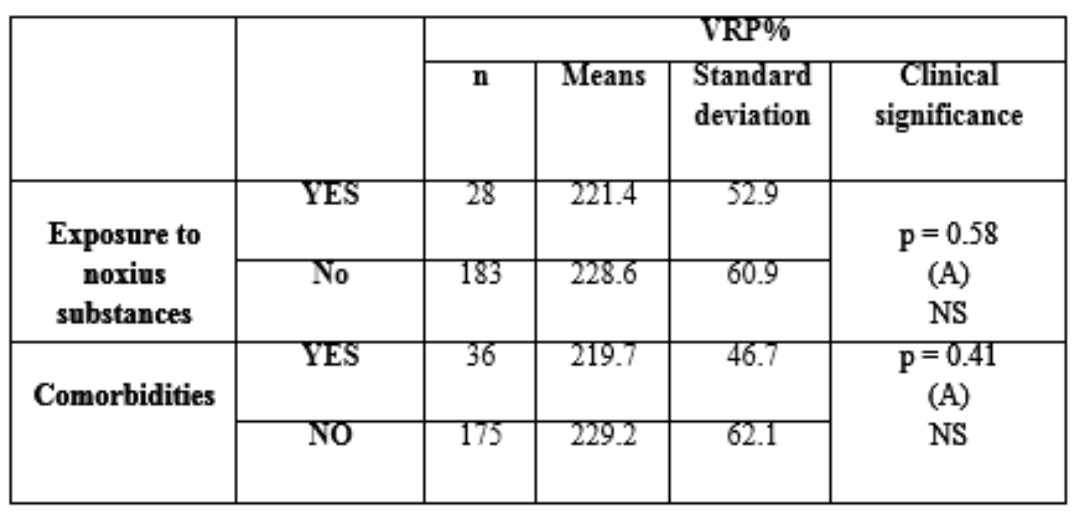

Fig. 4 VRP\% trend based on the PA number for the entire study group

Fig 5 VRP\% trend based on PA number for smokers

Table 8

ANALYSIS OF DIFFERENCES BETWEEN VRP\% EXPRESSED AS AVERAGES AND DEV. STANDARD ON SUBGROUPS RELATED TO THE STATUS OF SMOKER

Table 9

QUALITATIVE ANALYSIS OF EXPOSURE TO NOXIOUS SUBSTANCES OR THE PRESENCE OF CO-MORBIDITIES ON HYPERINFLATION
(SGRQa), symptom (SGRQs) score and total scores (SGRQt) of the hyperinflation groups studied (see table 11).

Patients with severe hyperinflation (77.5\%) had a significantly higher activity score $(p=0.04, A)$ than those with mild and moderate hyperinflation

Dividing into two groups (men and women) and studying differences in smoking history allowed a significant difference to be noted between the two groups. These differences were related to the onset of smoking $(F=0.35$; $p<0.01)$ and the number of smoking-year packs: PA ( $F=$
2.28; $p<0.01)$. This shows for the studied group, a much earlier start of smoking in men than women, a higher quantum of smoked packets, and a different pulmonary function ( $p<0.01$ for $\mathrm{FEV}_{1}$ ) and indicates a much higher susceptibility of female gender to develop COPD at a much lower smoker history than male, confirmed information and literature data [18-21].

Comparing the mean values and standard deviations of VRP\% for subgroups of patients with different nutritional status $(4,3,1)$ versus those with $\mathrm{BMI}$ group 2 (normoponderal), we found a significantly higher value of 


\begin{tabular}{|c|c|c|c|c|}
\hline \multicolumn{2}{|c|}{} & \multicolumn{3}{c|}{ Hyperinflation } \\
\cline { 2 - 5 } \multicolumn{2}{|c|}{} & YES & NO & Semnificație statistică \\
\hline Cor pulmonale & YES & 67 & 9 & $\begin{array}{c}\mathrm{P}=0.0001 \\
\left(\gamma^{2} \mathrm{Yc}\right) \\
\mathrm{R}=0.5 \\
0.27<\mathrm{RR}<0.85 \\
\mathrm{~S}\end{array}$ \\
\cline { 2 - 4 } & No & 7 & 9 & $\begin{array}{c} \\
\end{array}$ \\
\end{tabular}

Table 10

ANALYSIS OF THE PRESENCE OF CHRONIC PULMONARY CORD AS A RISK FACTOR FOR THE TIME DEGRADATION OF DIFFUSION THROUGH THE ALVEOLAR CAPILLARY MEMBRANE

\begin{tabular}{|c|c|c|c|c|c|}
\hline \multirow{3}{*}{$\begin{array}{l}\text { SGRQ } \\
\text { scores }\end{array}$} & \multicolumn{4}{|c|}{ Hyperinflation } & \multirow{3}{*}{$\begin{array}{l}\text { Satistical } \\
\text { significance } \\
\text { p-value }\end{array}$} \\
\hline & \multicolumn{2}{|c|}{ VRP $\%<180 \%$} & \multicolumn{2}{|c|}{ VRP $\% \geq 180 \%$} & \\
\hline & MEANS & $\begin{array}{l}\text { Standard } \\
\text { deviation }\end{array}$ & MEANS & $\begin{array}{l}\text { Standard } \\
\text { deviation }\end{array}$ & \\
\hline SGRQs & 70.7 & 18.1 & 66.2 & 19.0 & $\begin{array}{c}\mathrm{p}=0.38 \\
\text { (A) }\end{array}$ \\
\hline $\mathbf{n}$ & \multicolumn{2}{|c|}{85} & \multicolumn{2}{|c|}{126} & NS \\
\hline SGRQa & 70.3 & 23.8 & 72.4 & 19.8 & $\begin{array}{c}\mathrm{P}=0.04 \\
\text { (A) }\end{array}$ \\
\hline $\mathrm{n}$ & \multicolumn{2}{|c|}{85} & \multicolumn{2}{|c|}{126} & $\mathrm{~S}$ \\
\hline SGRQi & 48.5 & 16.9 & 45.3 & 18.6 & $\begin{array}{c}\mathrm{p}=0.50 \\
(\mathrm{~A})\end{array}$ \\
\hline $\mathbf{n}$ & \multicolumn{2}{|c|}{85} & \multicolumn{2}{|c|}{126} & $\mathrm{~S}$ \\
\hline SGRQt & 59.4 & 15.1 & 56.8 & 17.5 & $\begin{array}{c}\mathrm{p}=0.19 \\
\text { (A) }\end{array}$ \\
\hline $\mathrm{n}$ & \multicolumn{2}{|c|}{85} & \multicolumn{2}{|c|}{126} & $\mathrm{~S}$ \\
\hline
\end{tabular}

Table 11

SGRQ SCORES BASED ON WHETHER OR NOT SEVERE PULMONARY HYPERINFLATION hyperinflation at obese patients versus normoponderal patients $(p=0.046, A)$. But there is a paradox of obesity in patients with COPD. While in the general population, obesity is associated with an increased risk of mortality, Celli et al [22] finds that overweight and obesity are associated with a lower risk of death in patients with COPD.

Patients with severe hyperinflation had a significantly impact of quality of life activity score. They have a higher activity score $(p=0.04, A)$ than those with mild and moderate hyperinflation related because of decreasing the daily activities [23,24].

By analyzing the additional presence of noxious or other comorbidities (diabetes mellitus, hypertension, pulmonary neoplasm) on the severity of hyperinflation, we found no contribution as risk factors for increasing the residual volume in patients in the global group $[25,26]$.

Smoking cessation remain an important opportunity in the treatment of patients with COPD to avoid severe functional impairment and reducing the quality of life [27, 28].

\section{Conclusions}

The benefits of the approach to investigation (body plethysmography) for assessing and monitoring patients with COPD is very important. These will be taken into account in further investigation protocols because allows the calculation of pulmonary volumes, inaccessible to the routine spirometry method, essential parameters in the evaluation and long-term monitoring ofquality of life in patient with COPD, taking into account the limited information value of FEV1, performing a complete functional diagnosis for assessing the patient with COPD.

Only by calculating the residual volume can be found the value of the total pulmonary capacity and, implicitly, the correct assessment of the type of dysfunction, the pattern of patented obstructive ventilator dysfunction, the value of pulmonary hyperinflation, essential in the preoperative assessment and calculation of air-trapping volume.

\section{References}

1.***http//www.who.int/respiratory/copd/burden/en/ (2018).

2.SULLIVAN SD, RAMSEY SD, LEE TA. The economic burden of COPD.

Chest 2000; 117:5-9S

3.ANTO J M, VERMEIRE P, VESTBO J et al. Epidemiology of chronic obstructive pulmonary disease. Eur Respir J 2006; 17:982-984

4.SORIANO JB, MAIER WC, EGGER P et al. Recent trends in physician diagnosed COPD in women and men in UK. Thorax 2000; 55:789-794 5.J ONES PW, QUIRK FH, BAVEYSTOCK CM. The St George's Respiratory Questionnaire. Respir Med 1991; 85 Suppl B:25-31

6.J ONES PW, QUIRK FH, et al. A self-complete measure for chronic airflow limitation: the St. Geoge's Respiratory Questionnaire. Am Rev Respir Dis 1992; 145:1321-1327

7.CONSTANTIN B, POSTOLACHE P, CROITORU A, NEMES, RM. OcCUpational bronchial asthma - clinical and epidemiological aspects. J ournal Of Environmental Protection And Ecology 2015; 16(2): 517-520 8.*** 2019 GINA Report, Global Strategy for Asthma Management and Prevention https://ginasthma.org/wp-content/uploads/2019/06/GINA2019-main-report-June-2019-wms.pdf

9.CRIEE CP, SORICHTER S, SMITH HJ et al. Body plethysmography-its principles and clinical use. Respir Med. 2011 Jul;105(7):959-71

10.***Global Initiative for Chronic Obstructive Lung Disease (GOLD): Global Strategy for the Diagnosis, Management, and Prevention of Chronic Obstructive Pulmonary Disease NHLBI/WHO Workshop Report updated $2018 \mathrm{http}: / /$ www.goldcopd.com

11.STERK PJ. Let's not forget: the GOLD criteria for COPD are based on post-bronchodilator FEV1. Eur Respir J 2004; 23:497-498

12.DANTES E, FILDAN AP, TOMA CL, VOICU G, OANCEA C. Respiratory impact in workers exposed to air pollutants from petroleum refinery. J ournal of Environmental Protection and Ecology 2016; 17(2): 523-531

13.GOLLI AL, NITU MF, TURCU F, POPESCU M, CIOBANU-MITRACHE $L$, OLTEANU M. Tuberculosis remains a public health problem in Romania, Int J Tuberc Lung Dis, 2019; 23 (2), 226-231 
14.NEMES RM, IANOSI ES, POP CS, POSTOLACHE P, STREBA CT, OLTEANU M, GOLLI AL, OLTEANU M, NITU MF. Tuberculosis of the oral cavity. Rom J Morphol Embryol 2015, 56(2) : 521-525.

15.IORADACHE PD, MATESD, GUNARSSON B, EGGERTSSON HP, SULEM P, BENONISDOTTIR S, CSIKI IE, RASCU S, RADAVOI D, URSU R, STAICU C, CALOTA V, VOINOIU A, JINGA M, ROSOGA G, DANAU R, SIMA SC, BADESCU D, SUCIU N, RADOI V, MATES IN, DOBRA M, NICOLAE C et al. Identification of Lynch syndrome risk variants in the Romanian population. J Cell Mol Med. 2018; 22(12): 6068-6076.

16.GOLLI, A.L., NITU, F.M., BALASOIU, M., LUNGU, M.A., OLTEANU, M., NEMES, R.M., FORTOFOIU, M., RUSU, E., OLTEANU, M., Rev.Chim.(Bucharest),69, no.12, 2018, p.3433-3438

17.TANTU MM , MAN GM, PAUNESCU A. et al., Rev.Chim.(Bucharest),69, no.11, 2018, p.3001-3005

18.BUIST S, MAPP CE. Respiratory disease in women. European Respiratory Monograph 2003; 8:50-74

19.IANOSI, E.S., POSTOLACHE, P., MACOVEI, L.A., SZATHMARY, M., SZASZ, S., NEMES, R.M., JIMBOREAN, G., Smoking cessation in COPD patients by a selective partial nicotinic agonist. Rev.Chim. (Bucharest), 69, no.7, 2018, p.1766-1769

20.IANOSI, E.S., DANTES, E., CSIPOR, A., SZATHMARY, M., SOCACI, A., RUSU, E., NEMES, R.M., Enhancing education for smoking preventing and smoking cessation in medical personnel: a measure for a better health. Rev Chim (Bucharest), 69, no.10, p.2725-2727

21.JIMBOREAN, G., SZASZ, S., SZATHMARY, M., . CSIPOR A, ARGHIR OC, NEMES RM, POSTOLACHE P, IANOSI E. Association between chronic pulmonary disease and sleep apnea - overlap syndrome- experience of Pulmonology Clinic Tg. Mures, Romania, Rev.Chim.(Bucharest),69, no.4, 2018, p.1014-1017

22.CELLI BR, COTE CG et al. The body-mass index, airflow obstruction, dyspnea and exercise capacity index in chronic obstructive pulmonary disease. N Engl J Med 2004; 350:1005-1012

23.POSTOLACHE, P; NEMES, RM; PETRESCU, 0; MERISANU, IO. Smoking cessation, pulmonary rehabilitation and quality of life at smokers with COPD; Medical-Surgical J ournal 2015, Volume: 119 Issue: 1, 7780

24.POSTOLACHE P, NEMES RM, CROITORU A, CONSTANTIN B. The role of pulmonary rehabilitation in occupational COPD. J ournal of Environmental Protection and Ecology 2015, 16(2):521-527.

25.TANTU MM, MAN GM, ROGOZEA LM, DOMNARIU CD, PLESA FC, TRASCA DM, COTOI BV, STOICA LE, NICOLAE C, NEMES RM. Diabetic foot - epidemiological and histopathological aspects. Rom J Morphol Embryol 2018, 59(3): 895-902

26.TANTU, M.M, MAN, G.M., PAUNESCU, A., PLESA, F.C, NICOLAE, C., ROGOZEA, L.M., BISOC, A., MOSTAFA, M.F., NEMES, R.M., DIACONU, Rev.Chim.(Bucharest), 70, no.4, 2018, p.1307 - 1310

27.KETELAARS C, SCHLOSSER M, MOSTERT $R$ et al. Determinants of health-related quality of life in patients with chronic obstructive pulmonary disease. Thorax 1996; 51:39-43

28.HAJIRO T, NISHIMURA $K$ et al. Stages of desease severity and factors that affect the health status of pacients with chronic obstructive pulmonary disease. Respir Med 2000; 9:841-84.

Manuscript received: 14.05 .2019 